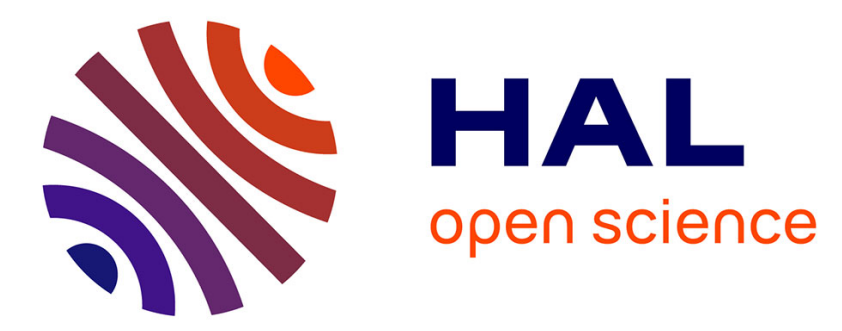

\title{
Effect of $\beta$-naphthoflavone and MCPA on liver and kidney drug-metabolizing enzymes from the carp, Cyprinus carpio
}

\author{
J.L. Riviere, A. Devaux, O. Gonin, Gilles Monod
}

\section{To cite this version:}

J.L. Riviere, A. Devaux, O. Gonin, Gilles Monod. Effect of $\beta$-naphthoflavone and MCPA on liver and kidney drug-metabolizing enzymes from the carp, Cyprinus carpio. Ecotoxicology and Environmental Safety, 1990, 19 (3), pp.276-284. 10.1016/0147-6513(90)90029-5 . hal-02715583

\section{HAL Id: hal-02715583 \\ https://hal.inrae.fr/hal-02715583}

Submitted on 1 Jun 2020

HAL is a multi-disciplinary open access archive for the deposit and dissemination of scientific research documents, whether they are published or not. The documents may come from teaching and research institutions in France or abroad, or from public or private research centers.
L'archive ouverte pluridisciplinaire HAL, est destinée au dépôt et à la diffusion de documents scientifiques de niveau recherche, publiés ou non, émanant des établissements d'enseignement et de recherche français ou étrangers, des laboratoires publics ou privés. 


\title{
Effect of $\beta$-Naphthoflavone and MCPA on Liver and Kidney Drug- Metabolizing Enzymes from the Carp, Cyprinus carpio ${ }^{1}$
}

\author{
J. L. Riviere, ${ }^{2}$ A. DeVAuX, O. Gonin, AND G. MONOD \\ Institut National de la Recherche Agronomique, Laboratoire d'Ecotoxicologie INRA-ENVL, \\ BP83, 69280 Marcy l'Etoile, France
}

Received November 18, 1988

\begin{abstract}
The effects of $\beta$-naphthoflavone ( $\beta$-NF) and a chlorophenoxyacetic acid herbicide (MCPA) on hepatic and renal monooxygenase activities and conjugating enzymes from immature carp (Cyprinus carpio) were studied. $\beta$-NF increased hepatic monooxygenase activities but the patterns of differential induction generally obtained in rat liver microsomes with two series of homologous substrates, alkoxycoumarins and alkylresorufins, were not found to be similar in carp liver microsomes. On the other hand, MCPA caused no changes in oxidative metabolism, with the exception of decreased aryl hydrocarbon hydroxylase activity. Renal activities were not modified by MCPA, while $\beta$-NF treatment resulted in marked increases in monooxygenase activities with alkylresorufins as substrates. No changes were found in conjugation activities after treatment with MCPA or $\beta$-NF. These results indicate that (a) the herbicide MCPA should have no effect on drug-metabolizing enzymes from carp, and (b) the hepatic and renal monooxygenase activities of carp are responsive to $\beta-\mathrm{NF}$, allowing their use in monitoring water pollution. (c) 1990 Academic Press, Inc.
\end{abstract}

\section{INTRODUCTION}

It is now well established that fish can metabolize xenobiotic compounds and are capable of increasing hepatic microsomal monooxygenase activities as a result of exposure to inducers. However, in contrast to mammals, fish do not respond to inducers of the phenobarbital type, while 3-methylcholanthrene, $\beta$-naphthoflavone, and polychlorobiphenyls cause high levels of induction (Chambers and Yarbrough, 1976; Addison et al., 1978; Lech and Bend, 1980; Andersson and Förlin, 1985; Andersson et al., 1985a; Payne et al., 1987). In addition to liver, the kidney of trout (Stegeman and Chevion, 1980; Andersson et al., 1985b; Williams et al., 1986; Pesonen and Andersson, 1987; Pesonen et al., 1987), scup (Stegeman et al., 1979), pike (Balk et al., 1984, 1985), vendace, perch and roach (Lindström-Seppä et al., 1981), carp (Melancon et al., 1981), and channel catfish (Tate, 1988) has been demonstrated to possess both phase I and phase II biotransformation systems. Studies on freshwater fish being less extensive than those concerned with marine species, the primary aim of this study was to more thoroughly characterize the inducing effects of $\beta$-naphthoflavone on enzymes of two organs, the liver and the kidney, of a freshwater fish, the carp. Particular attention was focused on two series of homologous substrates, alkylresorufins and alkoxycoumarins, which had been previously shown as useful probes to indicate the

\footnotetext{
${ }^{1}$ Presented in part as a poster at the "VIth International Congress on Biochemistry and Biophysics of Cytochrome P450, Vienna, 3-8 July 1988."

${ }^{2}$ To whom correspondence should be addressed.
} 
characteristics of induced monooxygenase activities in higher animals (Kamataki et al., 1980; Matsubara et al., 1983; Burke et al., 1985).

Moreover, recent reports have described the interaction of chlorophenoxyacid herbicides with several forms of rat liver drug-metabolizing enzymes, including induction of cytochrome P450-dependent monooxygenase, UDPG-transferase, and cytosolic and microsomal epoxide hydrolase activities (Hietanen et al., 1983; Lundgren et al., 1987), activation and inhibition of different forms of glutathione $S$-transferase (Dierickx, 1983; Vessey and Boyer, 1984) and also induction of cytochrome P452, the clofibrate-induced form of cytochrome P450 (Bacher and Gibson, 1988; Tamburini et al., 1984). In view of the actual concerns for the effects of pesticides on fish and other aquatic organisms, this prompted us to investigate the possible effects of MCPA (4-chloro-2-methylphenoxyacetic acid), a widely used herbicide, on some phase I and phase II activities in carp liver.

\section{MATERIALS AND METHODS}

Fish. Immature carps (Cyprinus carpio) were supplied by local fisheries. They were maintained in tap water at $14^{\circ} \mathrm{C}$ and were fed fish pellets ad libitum.

Chemicals. $\beta$-Naphthoflavone (5,6-benzoflavone, $\beta$-NF) was purchased from Aldrich, France. Alkoxycoumarins were synthesized from the alkyl iodides and umbelliferone by the method of Matsubara et al. (1982). Alkylresorufins were from Boehringer, France. NADP ${ }^{+}$, G6P, and G6P-DH were obtained from Boehringer, France. MCPA (free acid; 99.6\%) was a gift from Rhône-Poulenc Agrochimie, Lyon. All other chemical reagents and solvents used in the enzyme assays were of the highest commercial quality available.

Treatment of fish. Six carps were injected once intraperitoneally with a solution of the compound of interest in dimethylsulfoxide at $1.0 \mathrm{ml} / \mathrm{kg}$ body wt. The dosage levels were $100 \mathrm{mg} / \mathrm{kg}$, for both $\beta-\mathrm{NF}$ and MCPA. Controls were injected with the solvent alone. Fish were killed 2 days (control), 3 days (MCPA), and 4 days ( $\beta$-NF) after the injection. They were not fed during the experiment.

Preparation of subcellular fractions. Fish livers were homogenized in 3 vol of 0.15 $M \mathrm{KCl}, 50 \mathrm{~m} M$ phosphate buffer, $\mathrm{pH} 7.4$, using a Potter-Elvehjem homogenizer with three passes of a motor-driven Teflon pestle. Kidneys were homogenized in the same medium supplemented with $1 \mathrm{~m} M$ EDTA, ${ }^{3} \mathrm{Na}_{2}, 1 \mathrm{~m} M$ DTT, and $0.2 \mathrm{~m} M$ PMSF. The tissue homogenates were centrifuged in a Beckman J-21C centrifuge for $20 \mathrm{~min}$ at $10,000 \mathrm{~g}$ at $+4^{\circ} \mathrm{C}$. The supernatant was then recentrifuged in a Beckman L8-55 ultracentrifuge for $60 \mathrm{~min}$ at $105,000 \mathrm{~g}$ at $+4^{\circ} \mathrm{C}$. The microsomal pellet was resuspended in $50 \mathrm{~m} M$ phosphate buffer, pH 7.4, containing $1 \mathrm{~m} M$ DTT, $1 \mathrm{~m} M$ EDTA, and $20 \%$ glycerol and stored in small aliquots at $-80^{\circ} \mathrm{C}$. The microsomal supernatant was also frozen at $-80^{\circ} \mathrm{C}$. When maintained at this temperature, there was no loss of enzymatic activities until assay.

Enzyme assays. The monooxygenase reactions were alkylresorufin $O$-dealkylases (ethylresorufin, EROD; pentylresorufin, PROD; benzylresorufin, BROD), alkoxycoumarin $O$-dealkylases (methoxycoumarin, MCOD; ethoxycoumarin, ECOD; pro-

\footnotetext{
${ }^{3}$ Abbreviations used: DTT, dithiotreitol; G6P, glucose 6-phosphate; G6P-DH, glucose 6-phosphate dehydrogenase; PMSF, phenyl methyl sulfonyl fluoride; 3-MC, 3-methylcholanthrene; EDTA, $\mathrm{Na}_{2}$, ethylene diamino tetraacetate; UDPGA, uridine diphosphoglucuronosyl acid.
} 
poxycoumarin, PCOD; butoxycoumarin, BCOD), and benzo(a)pyrene hydroxylase (AHH). They were assayed in a final volume of $1 \mathrm{ml}$ containing $0.1 \mathrm{M}$ phosphate buffer, $\mathrm{pH} 7.4,0.5 \mathrm{~m} M \mathrm{NADP}^{+}, 5 \mathrm{~m} M$ G6P, 1 unit G6P-DH, microsomal protein, and substrate. The concentrations of substrates were: benzo( $a$ )pyrene (added in $40 \mu \mathrm{l}$ methanol), $0.080 \mathrm{mM}$, and alkoxycoumarins (in $10 \mu \mathrm{l}$ dimethylsulfoxide), $500 \mu M$. For measuring hepatic and renal EROD, PROD, and BROD activities, concentrations of substrates were $2.5,5$, and $5 \mu M$, respectively (added in $10 \mu \mathrm{DMSO}$ ). Reactions were stopped by $1 \mathrm{ml}$ acetone (AHH), $2 \mathrm{ml}$ acetone (alkylresorufins), or $100 \mu \mathrm{l}$ trichloracetic acid ( $20 \%$ in water; alkoxycoumarins). Hydroxylated metabolites of benzo( $a$ )pyrene were measured according to Nebert and Gelboin (1968). Results were expressed in relative fluorescence units (FU) where $1 \mathrm{FU}$ equals the fluorescence of a quinine sulfate solution $(1 \mu \mathrm{g} / \mathrm{ml})$. The fluorescence of 7-hydroxycoumarin was measured (excitation wavelength: $380 \mathrm{~nm}$; fluorescence wavelength: $480 \mathrm{~nm}$ ) after extraction of the product by ethyl acetate $(4 \mathrm{ml})$ and mixing $1 \mathrm{ml}$ of the organic phase with $1 \mathrm{ml}$ of ethanol and $1 \mathrm{ml}$ of glycine buffer $(\mathrm{pH} \mathrm{10.4)}$. The fluorescence of resorufin was measured according to the method of Rifkind and Muschick (1983). Fluorometer was standardized by 7-hydroxycoumarin or resorufin. All activities were performed at environmental temperatures $\left(+14^{\circ} \mathrm{C}\right)$.

UDPG-transferase activity was measured in activated microsomes $(4 \mathrm{mg}$ Triton $\mathrm{X}-100 / \mathrm{mg}$ of protein) by recording the decrease in absorbance at $405 \mathrm{~nm}$ and $+14^{\circ} \mathrm{C}$ of a solution containing microsomal protein $(1 \mathrm{mg} / \mathrm{ml})$, Tris- $\mathrm{HCl}$, $\mathrm{pH} 7.4(100 \mathrm{mM})$, 4-nitrophenol (0.105 $\mathrm{mM}$ ), $\mathrm{MgCl} 2$ ( $5 \mathrm{~m} M$ ), and UDPGA (2 $\mathrm{m} M$ ).

Glutathione $S$-transferase activity was assayed spectrophotometrically according to Habig et al. (1974) at $+14^{\circ} \mathrm{C}$ with 1-chloro-2,4-dinitrobenzene (CDNB), ethacrynic acid (EtAc), and $p$-nitrobenzyl chloride ( $p \mathrm{NBCl}$ ).

Cytochrome P450 content was measured according to Matsubara et al. (1976). Protein was determined by the method of Hartree (1972) with bovine serum albumin as a standard. All analyses were performed in duplicate.

Statistical analysis of results was performed by comparing treated and control groups with the Dunnett's $t$-test.

\section{RESULTS}

As can be seen from Table 1, there were no differences between MCPA-, $\beta$-NF-, and nontreated animals in terms of body weight, liver weight, and liver-to-body weight ratio. Renal microsomes and cytosol from $\beta$-NF-treated animals exhibited slightly higher protein content than preparations from control animals. On the other hand, hepatic microsomal protein in $\beta$-NF-treated animals was lower. The specific content of hepatic cytochrome P450 and microsomal UDPG-transferase activity were not modified by either treatment with the exception of cytochrome P450 which was increased by $\beta$-NF (Table 2 ). AHH activity was significantly depressed after treatment with MCPA but in contrast, treatment with $\beta$-NF resulted in a 10 -fold increase (Table 2). Hepatic and renal cytochrome P450-dependent activities toward three alkylresorufins are shown in Fig. 1. Overall, activities were higher in liver than in kidney of control animals. EROD activity was highest in both organs, followed by BROD and PROD. The levels of PROD (in liver) and BROD and PROD activities (in kidney) were so low as to be undetectable. There was no effect of MCPA on either liver and kidney activities. A single injection of $\beta$-NF resulted in a strong induction of all 
TABLE 1

BODY WEIGHT, LIVER WEIGHT, AND PROTEINS IN CONTROL AND IN $\beta$-NF- AND MCPA-TREATED CARP

\begin{tabular}{lccc}
\hline & Control & MCPA & $\beta$-NF \\
\hline Body weight (g) & $416 \pm 41^{a}$ & $467 \pm 31$ & $472 \pm 37$ \\
Liver weight (g) & $14.8 \pm 2.1$ & $16.2 \pm 2.0$ & $17.7 \pm 2.8$ \\
Ratio (liver weight/body weight) & & & \\
$\quad \times 100$ & 3.55 & 3.47 & 3.75 \\
Microsomal protein: & $9.2 \pm 0.3$ & $10.2 \pm 0.3$ & $7.5 \pm 0.4^{* *}$ \\
$\quad$ Liver (mg/g) & $7.6 \pm 0.2$ & $9.0 \pm 0.4$ & $9.4 \pm 0.7^{*}$ \\
$\quad$ Kidney (mg/g) & $40.4 \pm 0.7$ & $42.4 \pm 1.5$ & $42.4 \pm 1.1$ \\
Cytosolic protein: & $39.6 \pm 1.1$ & $43.2 \pm 1.1$ & $47.2 \pm 1.0^{*}$ \\
$\quad$ Liver (mg/g) & & &
\end{tabular}

${ }^{a}$ Mean \pm SEM of six animals, significantly different from control group at ${ }^{*} P<0.05$ and ${ }^{* *} P<0.01$.

hepatic and renal metabolism of alkylresorufins. EROD activity in kidney and EROD and BROD activities in liver were induced 60-, 12.3-, and 11.4-fold, respectively. As a result of the lack of detectable activity in control animals, the rate of induction was not calculated for the other activities. Hepatic and renal glutathione $S$-transferase activities toward three substrates are illustrated in Fig. 2. Kidney had activity toward CDNB comparable to that of liver and the highest activity toward EtAc, while liver had the highest activity toward $\mathrm{NBCl}$. There was no significant effect of MCPA or $\beta$-NF treatment on these activities.

When assayed with hepatic microsomes, the metabolism of alkoxycoumarins showed some striking features (Fig. 3). The order of specific activity was ECOD $>$ PCOD > MCOD > BCOD (as compared by the Newman-Keuls's test). Pretreatment of carp with MCP $\Lambda$ did not modify the above activities, but pretreatment with $\beta$-NF resulted in a 4.2-, 3.2-, 2.3-, and 1.6-fold induction of MCOD, ECOD, PCOD, and $\mathrm{BCOD}$, respectively.

\section{DISCUSSION}

$\beta$-NF is a good inducer of hepatic AHH in carp and slightly elevates cytochrome P450 content. Our results agree well with those of Melancon et al. (1981), who treated carp with $\beta$-NF under very similar conditions.

\section{TABLE 2}

Drug-Metabolizing ENZYME ACTIVITIES IN LIVER MiCrosomeS From CONTROL AND FROM MCPA- AND $\beta$-NF-TREATED CARP

\begin{tabular}{lccc}
\hline & Control & MCPA & $\beta$-NF \\
\hline AHH $^{\alpha}$ & $1.03 \pm 0.16^{b}$ & $0.60 \pm 0.07^{*}$ & $10.1 \pm 1.5^{* *}$ \\
Cytochrome P450 $^{c}$ & $374 \pm 23$ & $340 \pm 12$ & $447 \pm 28^{*}$ \\
UDPG-transferase activity $^{d}$ & $325 \pm 28$ & $244 \pm 40$ & $300 \pm 30$ \\
\hline
\end{tabular}

${ }^{a} \mathrm{FU} / \mathrm{mg} / \mathrm{min}$.

${ }^{b}$ Mean \pm SEM of six animals, significantly different from control group at ${ }^{*} P<0.05$ and ${ }^{* *} P<0.01$.

${ }^{c} \mathrm{pmol} / \mathrm{mg}$.

${ }^{d} \mathrm{pmol} / \mathrm{mg} / \mathrm{min}$. 

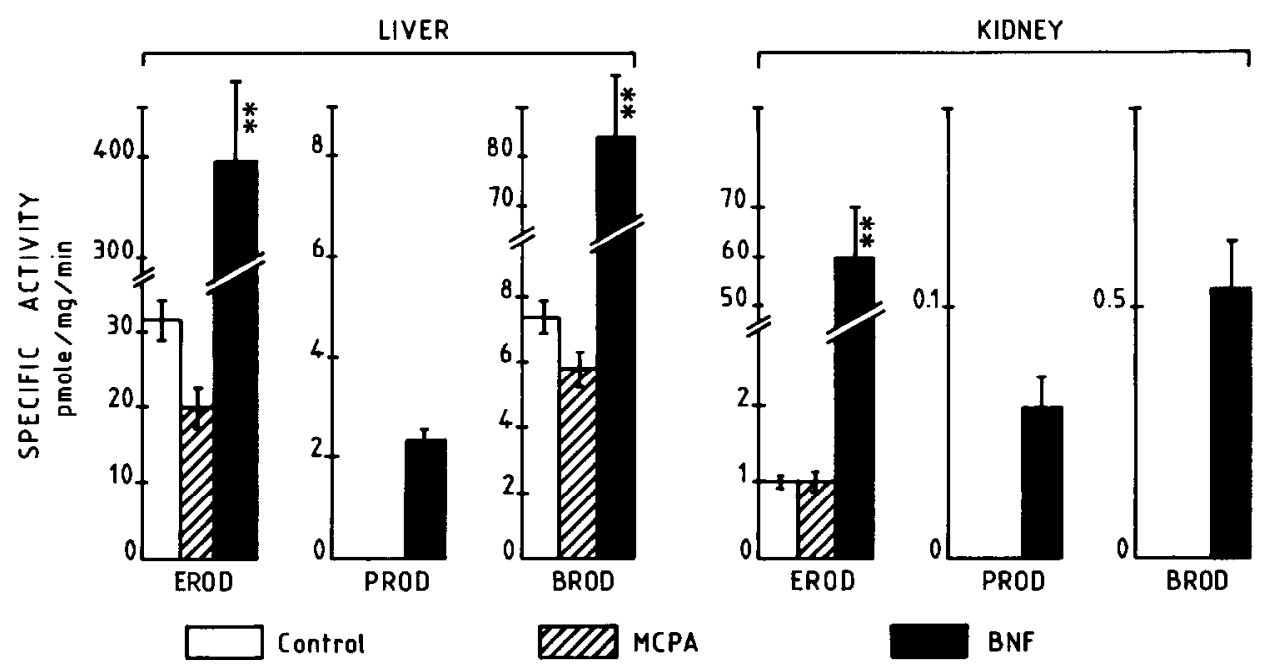

FIG. 1. Effects of $\beta$-NF and MCPA on the microsomal alkylresorufin $O$-dealkylase activities (EROD, ethylresorufin $O$-deethylase; PROD, pentylresorufin $O$-depentylase; BROD, benzylresorufin $O$-debenzylase) in the liver and kidney of carp. Results are means \pm SEM of six animals, significantly different from control group at ${ }^{*} P<0.05$ and ${ }^{* *} P<0.01$.

It was previously shown that alkylresorufins should be used for characterizing hepatic cytochrome P450 induction (Burke et al., 1985). In rat liver, $\beta$-NF and 3-MC treatment resulted in a large induction of EROD activity ( $>50$-fold) compared to that of PROD and BROD activities (6- to 17-fold). In trout liver, these three activities, EROD, PROD and BROD, were increased by treatment with $\beta$-NF 61-, 6.5-, and 1.2-fold, respectively (Addison et al., 1987). On the other hand, treatment of channel catfish with 3-MC produced marked increases in EROD, but also in BROD and PROD activities (Ankley et al., 1987), which is more similar to our results in view of the high rate of induction of BROD activity in carp microsomes. Hepatic alkoxycoumarins activities were also demonstrated to be differentially induced in rodent species: phenobarbital increased all activities, while 3-MC and $\beta$-NF did not increase MCOD activity, but strongly enhanced the other activities (Kamataki et al., 1980; Matsubara et al., 1983). In sharp contrast with this situation, the rate of induction in carp liver was in inverse ratio to the length of the alkyl chain of the substrate, i.e., MCOD was the most induced activity. Unfortunately, no other reports are available in the fish literature for comparison. These observations point out the large differences in substrate specificity which occur in cytochrome P450 from different animal species after treatment with the same group of inducers and the difficulty of discriminating between different classes of inducers by using model substrates.

Microsomal UDPG-transferase and cytosolic glutathione $S$-transferases activities were studied to assess the possible effects of MCPA and $\beta$-NF treatments upon enzymes which catalyze the further metabolism of cytochrome $\mathrm{P} 450$ reaction products. UDPG-transferase activity was assayed in the activated form. No clear-cut effects of $\beta$-NF on conjugating enzymes were found in carp, in agreement with the data of Tate (1988), who did not find induction of conjugation of 4-methylumbelliferone with UDPGA or chlorodinitrobenzene with glutathione after $\beta$-NF administration to channel catfish. However, Andersson et al. (1985a) reported a two- to threefold in- 
LIVER

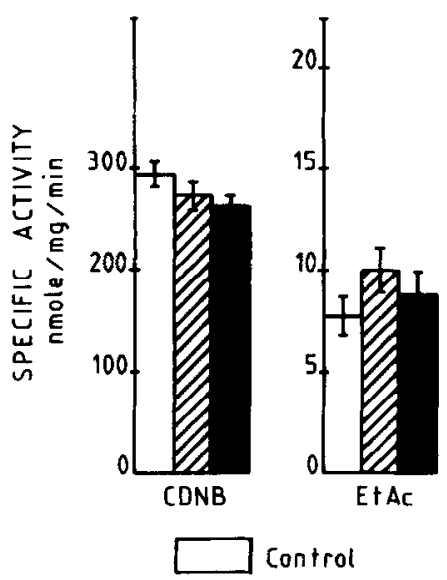

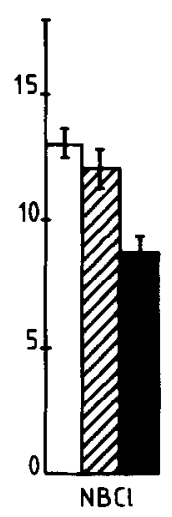

QDA MCPA

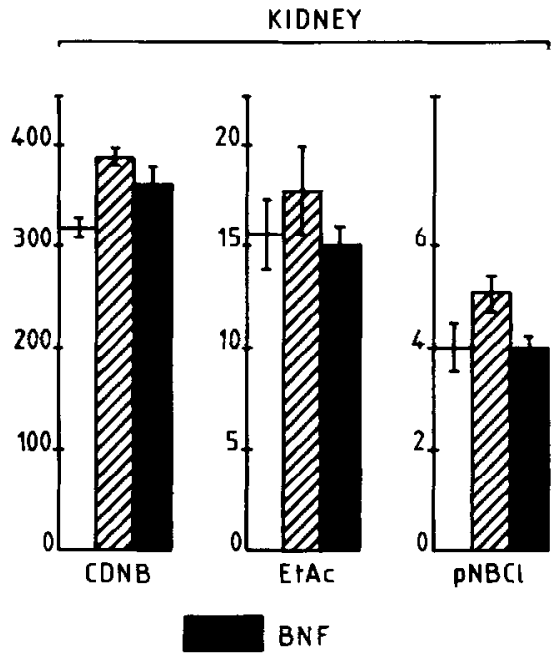

FIG. 2. Effects of $\beta$-NF and MCPA on cytosolic glutathione $S$-transferase activities from liver and kidney of carp (substrates were: CDNB, 1-chloro-2,4-dinitrobenzene; EtAc, ethacrynic acid; pNBCl, $p$-nitrobenzyl chloride). Results are means \pm SEM of six animals, significantly different from control group at $* P<0.05$ and ${ }^{* *} P<0.01$.

crease in UDPG-transferase activity toward 4-nitrophenol in trout liver microsomes after administration of the same compound. The latter group also observed that the glutathione $S$-transferase activity was elevated twofold after treatment with $\beta$-NF but induction was obtained 1-2 weeks after the treatment. No changes in glutathione $S$ transferase activity were found in another study (Andersson et al., 1985b).

In fish as in other vertebrates, the kidney is the major route for elimination of xenobiotic compounds, and data show a more rapid clearance of these compounds in
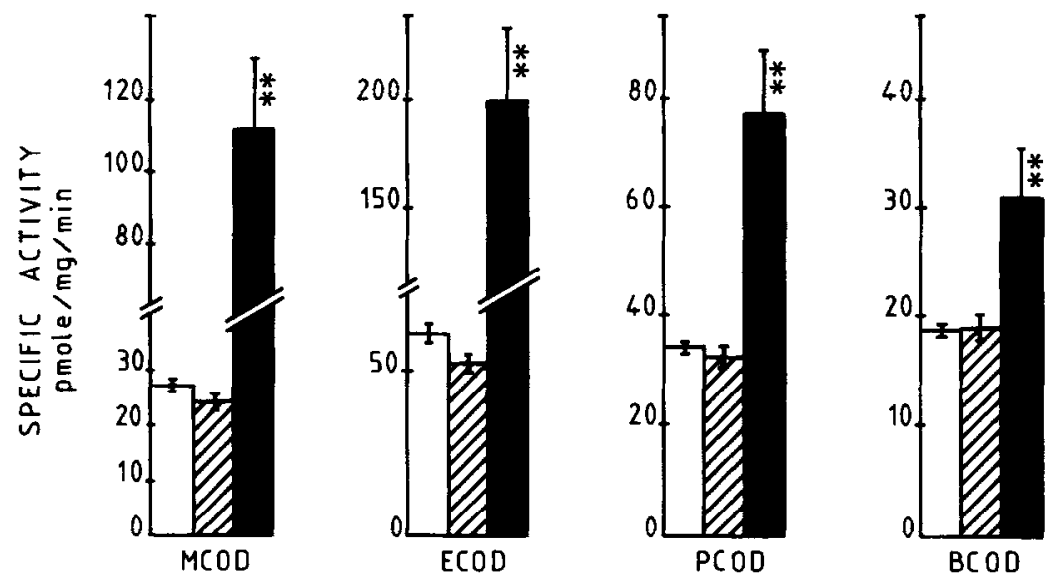

FIG. 3. Effects of $\beta$-NF and MCPA on the microsomal alkoxycoumarin $O$-dealkylase activities (MCOD, methoxycoumarin $O$-demethylase; ECOD, ethoxycoumarin $O$-deethylase; PCOD, propoxycoumarin $O$ depropylase; $B C O D$, butoxycoumarin $O$-debutylase) in the liver of the carp. Results are means $\pm S E M$ of six animals, significantly different from control group at ${ }^{*} P<0.05$ and ${ }^{* *} P<0.01$. 
fish than in other species, e.g., dog or man (Pritchard and Bend, 1984). Furthermore, kidney should be an important organ in biotransformation because under environmental conditions the uptake of pollutants occurs through the gills; then organic molecules are directed mainly to the kidney with arterial blood, whereas the major fraction of ip-injected xenobiotic compounds reach the liver where they are cleared by biliary elimination (Pesonen et al., 1987). A marked species difference exists in the induction of renal and hepatic monooxygenase activities in rodents (Lake et al., 1973; Litterst $e$ t al., 1977; Smith et al., 1986). In fish, similar discrepancies were also found. It was shown by Pesonen and Andersson (1987) that the patterns of time-dependent increase in EROD activity were similar in kidney and liver of rainbow trout, although a dose-dependent effect was found. Induction of salmon and flounder benzo( $a$ )pyrene hydroxylase was observed in kidney before liver (Truscott et al., 1983), and Payne et al. (1984) reported induction of AHH in kidney of flounder, but not in liver. In contrast with these data, Tate (1988) has shown that $\beta$-NF treatment of immature channel catfish did not result in an increase in renal EROD, although induction was observed in liver microsomes but to a lesser extent, about four- to fivefold. More surprising was the lack of renal induction of EROD after pretreatment of carp with $\beta$-NF under experimental conditions similar to ours (Melancon et al., 1981). Our study is the first to compare BROD and PROD activities in fish kidney before and after $\beta$-NF treatment and to show the inducibility of these activities by this compound. As in trout (Andersson et al., 1985b), cytosolic renal glutathione $S$-transferases were not modified in carp by treatment with $\beta$-NF.

Recently, Bacher and Gibson (1988) have shown that some chlorophenoxyacid herbicides modify cytochrome P450 content as well as different cytochrome P450dependent activities from rat liver. They found that MCPA $(200 \mathrm{mg} / \mathrm{kg}$ per os for 3 days) caused an increase in cytochrome P450 level (1.6-fold), EROD activity (2-fold), and lauric acid 12-hydroxylase and 11-hydroxylase (3.5- and 1.5-fold, respectively). In contrast with the results found in rat, MCPA had no effect on EROD activity in carp liver, despite the use of a relatively high dosage of this compound. The glutathione $S$-transferases from carp liver were recently shown to be sensitive to inhibition (in the millimolar range) by 2,4-dichlorophenoxyacetic acid (Dierickx, 1985), but the relevance of these data in terms of in vivo administration remains doubtful.

\section{CONCLUSIONS}

The results obtained in the present study clearly demonstrate that both liver and kidney from carp possess inducible monooxygenase activities, useful for monitoring water pollution (Payne et al., 1987). However, alkylresorufins and alkoxycoumarins are likely not valuable tools for discriminating hepatic induction by $\beta$-NF and related compounds and by phenobarbital. The various effects shown by MCPA in rat liver were not found in carp liver, which should be of interest to evaluate the environmental impact of this herbicide on fish.

\section{ACKNOWLEDGMENTS}

We thank Dr. R. Barret for synthesizing and purifying the alkoxycoumarins used in this study. Fxcellent technical assistance was provided by Michèle Mazallon. This work was supported in part by a grant from SRETIE, Ministère de l'Environnement, France. 


\section{REFERENCES}

ADDISON, R. F., ZINCK, M. E., AND WILLIS, D. E. (1978). Induction of hepatic mixed-function oxidase (MFO) enzymes in trout (Salvelinus fontinalis) by feeding Aroclor 1254 or 3-methylcholanthrene. Comp. Biochem. Physiol. C61, 323-32.

ADDISON, R. F., SADLER, M. C., AND LUBET, R. A. (1987). Absence of hepatic microsomal pentyl- or benzyl-resorufin $O$-dealkylase induction in rainbow trout (Salmo gairdneri) treated with phenobarbitone. Biochem. Pharmacol. 36, 1183-1184.

ANDERSSON, T., AND FöRLIN, L. (1985). Spectral properties of substrate-cytochrome P-450 interaction and catalytic activity of xenobiotic metabolizing enzymes in isolated rainbow trout liver cells. Biochem. Pharmacol. 34, 1407-1413.

Andersson, T., Pesonen, M., and Johansson, C. (1985a). Differential induction of cytochrome P-450dependent monooxygenase, epoxide hydrolase, glutathione transferase and UDP glucuronosyl transferase activities in the liver of the rainbow trout by $\beta$-naphthoflavone or Clophen A50. Biochem. Pharmacol. 34, 3309-3314.

ANDERSSON, T., KoIvusaARI, U., AND FöRLIN, L. (1985b). Xenobiotic biotransformation in the rainbow trout liver and kidney during starvation. Comp. Biochem. Physiol. C 82, 221-225.

ANKLEY, G. T., REINERT, R. E., MAYER, K. T., BURKE, M. D., AND AGOSIN, M. (1987). Metabolism of alkoxyphenoxazones by channel catfish liver microsomes: Effect of phenobarbital, Aroclor 1254 and 3methylcholanthrene. Biochem. Pharmacol. 36, 1379-1381.

BACHER, M. A., AND GiBson, G. G. (1988). Chlorophenoxyacid herbicides induce microsomal cytochrome P-450IVA I (P-452) in rat liver. Chem.-Biol. Interact, 65, 145-156.

Balk, L., Maner, S., Bergstrand, A., ANd DePierre, J. W. (1984). Preparation and characterization of subcellular fractions suitable for studies of drug metabolism from the trunk kidney of the Northern pike (Esox lucius) and assay of certain enzymes of xenobiotic metabolism in these subfractions. Biochem. Pharmacol. 33, 2447-2459.

Balk, L., Maner, S., Bergstrand, A., Birberg, W., Pilotti, A., And DePierre, J. W. (1985). Preparation and characterization of subcellular fractions from the head kidney of the Northern pike (Esox (ucius), with particular emphasis on xenobiotic-metabolizing enzymes. Biochem. Pharmacol. 34, 789802.

Burke, M. D., Thompson, S., Elcombe, C. R., Halpert, J., Haaparanta, T., and Mayer, R. T. (1985). Ethoxy-, pentoxy- and benzyloxyphenoxazones and homologues: A series of substrates to distinguish between different induced cytochromes P-450. Biochem. Pharmacol. 34, 3337-3345.

Chambers, J. E., AND Yarbrough, J. D. (1976). Xenobiotic biotransformation system in fishes. Comp. Biochem. Physiol. C 55, 77-84.

DIERICKX, P. J. (1983). Interaction of chlorophenoxyalkyl acid herbicides with rat-liver glutathione $S$ transferases. Food Chem. Toxicol. 21, 575-579.

DIERICKX, P. J. (1985). Purification and partial characterization of the glutathione $S$-transferases in carp liver, and their interaction with 2,4-dichlorophenoxyacetic acid and 1,4-benzoquinone. Biochem. Int. $11,55-763$.

HABIG, W. H., PABST, M. J., AND JAKOBY, W. B. (1974). The first enzymatic step in mercapturic acid formation. J. Biol. Chem. 249, 7130-7139.

HARTREE, E. F. (1972). Determination of protein: A modification of the Lowry method that gives a linear photometric response. Anal. Biochem. 48, 422-427.

Hietanen, E., LinnainmaA, K., AND Vainio, H. (1983). Effects of phenoxyherbicides and glyphosate on the hepatic and intestinal biotransformation activities in the rat. Acta Pharmacol. Toxicol. 53, 103-112.

Kamataki, T., ANDO, M., Yamazoe, Y., ISHI, K., AND Kato, R. (1980). Sex-difference in the $O$-dealkylation activity of 7-hydroxycoumarin $O$-alkyl derivatives in liver microsomes of rats. Biochem. Pharmacol. 29, 1015-1022.

Lake, B. G., Hopkins, R., Chakraborty, J., Bridges, J. W., and Parke, D. V. W. (1973). The influence of some hepatic enzyme inducers and inhibitors on extrahepatic drug metabolism. Drug Metab. Dispos. 1, 342-349.

LECH, J. J., AND BEND, J. R. (1980). Relationship between biotransformation and the toxicity and fate of xenobiotic chemicals in fish. Environ. Health Perspec. 34, 115-131.

LINDSTRÖM-SEPP ̈̈, P., KOIVUSAARI, U., AND HÄNNINFN, O. (1981). Fxtrahepatic xenobiotic metabolism in North-european freshwater fish. Comp. Biochem. Physiol. C69, 259-263.

Litterst, C. L., Mimnaugh, E. G., AND Gram, T. E. (1977). Comparative alterations in extrahepatic drug metabolism by factors known to affect hepatic activity. Biochem. Pharmacol. 26, 749-755. 
LUNDGREN, B., MEIJER, J., AND DEPIERRE, J. W. (1987). Induction of cytosolic and microsomal epoxide hydrolases and proliferation of peroxisomes and mitochondria in mouse liver after dietary exposure to $p$-chlorophenoxyacetic acid, 2,4-dichlorophenoxyacetic acid and 2,4,5-trichlorophenoxyacetic acid. Biochem. Pharmacol. 36, 815-821.

Matsubara, T., KoIKe, M., Touchi, A., Tochino, Y., AND Sugeno, K. (1976). Quantitative determination of cytochrome $\mathrm{P}-450$ in rat liver homogenate. Anal. Biochem. 75, 596-603.

Matsubara, T., Yoshihara, E., Iwata, T., Tochino, Y., and HaChino, Y. (1982). Biotransformation of coumarin derivatives (1) 7-alkoxycoumarin $O$-dealkylase in liver microsomes. Japan. J. Pharmacol. 32, 9-21.

Matsubara, T., Otsubo, S., ANd Yoshihara, E. (1983). Liver microsomal cytochrome P-450-dependent $O$-dealkylation reaction in various animals. Japan. J. Pharmacol. 33, 1065-1075.

MelanCON, M. J., ElCOMBE, C. R., VodiCNIK, M. J., AND LECH, J. J. (1981). Induction of cytochromes $\mathrm{P} 450$ and mixed-function oxidase activity by polychlorinated biphenyls and $\beta$-naphthoflavone in carp (Cyprinus carpio). Comp. Biochem. Physiol. C69, 219-226.

NeberT, D. W., AND Gelboin, H. V. (1968). Substrate-inducible microsomal aryl hydroxylase in mammalian cell culture. I. Assay and properties of induced enzyme. J. Biol. Chem. 243, 6242-6249.

Payne, J. F., Bauld, C., Dey, A. C., KiceniuK, J. W., AND Williams, U. (1984). Selectivity of mixedfunction oxygenase induction in flounder (Pseudopleuronectes americanus) collected at the site of the Baie Verte, Newfoundland oil spill. Comp. Biochem. Physiol. C 79, 15-19.

Payne, J. F., Fancey, L. L., Rahimtula, A. D., AND Porter, E. L. (1987). Review and perspective on the use of mixed-function oxygenase enzymes in biological monitoring. Comp. Biochem. Physiol. C 86, $233-245$.

PEsOnen, M., AND ANDERsson, T. (1987). Subcellular localization and properties of cytochrome P-450 and UDP-glucuronosyltransferase in the rainbow trout kidney. Biochem. Pharmacol. 36, 823-829.

Pesonen, M., Celander, M., Förlin, L., AND ANDERsson, T. (1987). Comparison of xenobiotic biotransformation enzymes in kidney and liver of rainbow trout (Salmo gairdneri). Toxicol. Appl. Pharmacol. 91, 75-84.

Pritchard, J. B., AND Bend, J. R. (1984). Mechanisms controlling the renal excretion of xenobiotics in fish: Effects of chemical structure. Drug Metab. Rev. 15, 655-671.

RIFKIND, A. B., AND MUSCHICK, H. (1983). Benoxaprofen suppression of polychlorinated biphenyl toxicity without alteration of mixed function oxidase function. Nature (London) 303, 524-526.

SMITH, J. H., RuSH, G. F., AND HoOK, J. B. (1986). Induction of renal and hepatic mixed function oxidases in the hamster and guinea pig. Toxicology 38, 209-218.

Stegeman, J. J., Binder, R. L., AND ORREN, A. (1979). Hepatic and extrahepatic microsomal electron transport components and mixed-function oxygenases in the marine fish Stenotomus versicolor. Biochem. Pharmacol. 28, 3431-3439.

Stegeman, J. J., And Chevion, M. (1980). Sex differences in cytochrome P-450 and mixed-function oxygenase activity in gonadally mature trout. Biochem. Pharmacol. 29, 553-558.

Tamburini, P. P., Masson, H. A., Bains, S. K., Makowski, R. J., Morris, B., and Gibson, G. G. (1984). Multiple forms of hepatic cytochrome P-450. Purification, characterisation and comparison of a novel clofibrate-induced isozyme with other major forms of cytochrome P-450. Eur. J. Biochem. 139, 235-246.

TATE, L. G. (1988). Characterization of phase I and phase II drug metabolism and the effect of $\beta$-naphthoflavone in the liver and posterior kidney of the channel catfish. Arch. Environ. Contam. Toxicol. 17, 325-332.

Truscott, B., Walsh, J. M., Burton, M. P., Payne, J. F., And IDler, D. R. (1983). Effect of acute exposure to crude petroleum on some reproductive hormones in salmon and flounder. Comp. Biochem. Physiol. C 75, 121-130.

VESSEY, D. A., AND BOYER, T. D. (1984). Differential activation and inhibition of different forms of rat liver glutathione $S$-transferases by the herbicides 2,4-dichlorophenoxyacetate (2,4-D) and 2,4,5-trichlorophenoxyacetate (2,4,5-T). Toxicol. Appl. Pharmacol. 73, 92-499.

Williams, D. E., MASTERS, B. S. S., LECH, J. J., AND BUHLER, D. R. (1986). Sex differences in cytochrome $\mathrm{P}-450$ isozyme composition and activity in kidney microsomes of mature rainbow trout. Biochem. Pharmacol. 35, 2017-2023. 